Pakistan Journal of Humanities and Social Sciences

October - December 2018, Volume 6, No. 4, Pages 428 - 442

\title{
Zulfiqar Ali Bhutto's Speech in United Nations' Security Council (UNSC) on September 22, 1965: Critical Discourse Analysis Perspective
}

\author{
Muhammad Sibtain Chohan ${ }^{1}$, Muhammad Nadeem Anwar ${ }^{2}$ \\ ${ }^{1}$ Lecturer in English NCBA, DHA Campus Lahore, Pakistan \\ 2 Assistant Professor of English, Higher Education Department, Government College of \\ Science, Wahdat Road Lahore. \\ Email: msibtainc@gmail.com
}

\begin{abstract}
The aim of the study is to analyze Zulfiqar Ali Bhutto's speech at United Nations' Security Council on September 22, 1965. The study attempts to uncover the meanings of the words employed to show the core tension of 1965 war between Pakistan and India. There have been different models of CDA presented by scholars like Fairclough, Wodak and Van Dijk, but the most suitable CDA framework for this study case is of Van Dijk. His (1997) framework for critical discourse analysis provides the clear picture of the ideologies expressed in various kinds of structures. Qualitative methodology has been employed for this study and the content of the speech was analyzed qualitatively. The findings of the study elaborate that Bhutto was determined to have a permanent peace in the region. It can also be observed that he was quite confident in buying peace for Pakistani and the neighboring countries. He reinforced the subject matter with multiple instances of the countries that faced the same war-like circumstances and rose again with new zeal and zest. The study has its theoretical as well as practical scope.
\end{abstract}

Keywords: Critical discourse analysis, ideological meaning, socio-cognition, Z.A Bhutto's speech, 1965 war between India and Pakistan

\section{Introduction}

Zulfiqar Ali Bhutto is one of the greatest politicians of Pakistan. He stepped into politics in 1958 as the Commerce Minister of the President Iskander Mirza's Cabinet and was the youngest minister in Ayub Khan's Cabinet. He became the Foreign Minister in 1963. He contributed to the betterment of the country in the form of introducing reforms, schemes, policies, publications of pharmacopoeia, integral rural development programs, people's work programs, national volunteer development program, Sino-Pakistan boundary agreement, 
Pakistan Journal of Humanities and Social Sciences, 6(4), 2018

better foreign relations with neighbors as well as well established countries of the world, Simla agreement, 1973 Constitution of Pakistan, Hamudur-Rehman Commission Report etc. There have been many books, articles, and talks made in the remembrance of Bhutto that it seems his death are bigger than his life.

Bhutto was the fulcrum of the politics of Pakistan as he was needed at all times. Due to some political upheavals when Iskander Mirza was deposed Bhutto was forced to resign, Ayub Khan did not accept the resignation and said: "the country needed a Commerce Minister of his caliber". According to Junejo (1996), he had the same importance as the foreign minister of Pakistan, he tried to put his resignation to Ayub Khan's pocket many time but he cajoled and begged him to remain in his position. In 1965, when the war was uncontrollable, Ayub Khan requested the United States Ambassador for American intervention to stop the conflict. S. M. Zafar, the law minister attempted to convince UN Security Council on the dispute of war between Pakistan and India, he lost the audience and everything was going against Pakistan. Then Bhutto was plunged into the immediate situation and he controlled it so well. The speech was emotionally charged and had its effects on the members of the council and the people of Pakistan who broke into tears when Bhutto stated:

"We will wage war for a thousand years; a war of defiance ... we shall fight in self-defense, we shall fight for honor. We do not want to be exterminated, we cherish life. We want to live, we want our people to live ... but we are resolved to fight for our honor, to fight for Pakistan." (Bhutto, 1965).

Truly, Zulfiqar Ali Bhutto's speech had such strength which resulted in the favor of not only the two countries but also for the peace in the region, as UNSC released the decision (see Appendix II).

\section{Theoretical Background}

\section{A. Discourse Analysis}

Undoubtedly, discourse analysis is developing and changing as a field. This field has multidimensional approaches which are different from one another. There have been many definitions of the word "Discourse", which sometimes confuse the newcomers to understand the actual purpose of the word and relevant benefits to the field. For narrowing the study, Gee (1999) coins the definition of the term "discourse" with "small-d-discourse" which means the actual text and talk whereas "big-D-discourse" indicates the knowledge presented in the text or talk, which later on becomes the social practice through the systems of thoughts, contemplations, views and assumptions of the members of the society. Whereas "Discourse 
Analysis" can be divided into two types of levels when it is defined as the meaning of particular text or talk, one is utterance-type meaning, and another is utterance-token meaning (Levinson, 2000). The first level shows the "general meaning" of the particular discourse and the latter presents the "situated meaning". The utterance-type meaning involves two levels "form" and "function". Form stands for morphemes, words, phrases, or other syntactic structure. And "function" signifies the communicative purpose of the form. The other type "the utterance-token meaning" includes the study of the connection between form and function in language as well as it discovers the tasks of situational and situated meanings of forms expressed in certain contexts. To understand the broader perspective of the term "discourse analysis" many eminent linguists have defined it with their distinctive style as according to Titcher et el. (1998, p. 42) Discourse "integrates a whole pallet of meanings". Van Dijk (2003) supposes that one of the best illustrations of any discourse analysis appears in the so-called relationship of text and the context in which that text is (re)produced. He adds that the word "discourse" is grasped as a text within a text in which data is subjected to empirical investigations. Moreover, Fairclough (1989) describes that discourse is a complete practice of social interaction in which text is just a segment, affected by other extraordinary linguistic components such as the speaker, audience or spectators, and occasions. Whereas Van Dijk (1988) deems that "discourse" is a complex form of conversation rather than a separate text or talk, in fact it encapsulates a social context, which involves participants, production and reception procedures.

\section{B. Critical Discourse Analysis (CDA)}

Critical Discourse Analysis emerged with the development of the subjects in the field of social sciences such as 'critical psychology', 'critical social policy' and 'critical anthropology.' According to Agger (1992b) and Rasmussen (1996), some of the critical theories pertaining to critical discourse analysis can be found in the Frankfurt School before the Second World War. Fowler et al. (1979) and Mey (1985) state that, "critical linguistics" emerged at the end of the 1970s in the UK and Australia and focused on language and discourse. Fairclough (1992a) also used the title 'critical linguistics'. Further he articulates that critical discourse analysis comprises on three levels which are text, discursive practice and social practice. And Van Dijk's (2009) CDA approach has a clear resemblance as it deals discourse, cognitive and society which ultimately completes the same triangulation. According to Anthonissen (2001), nowadays, the term CDA particularly refers to the scholars of critical linguistics who consider the discursive unit of text or talk as the fundamental unit 
Pakistan Journal of Humanities and Social Sciences, 6(4), 2018

of any communicative event. For Fairclough (1995), a discourse signifies a definite area of social practice from a particular outlook. Targets of CDA, according to Van Dijk (1993) are those established groups who exercise power to maintain inequality and injustice in the society. CDA is a kind of an analytical research on the particular discourse that initially highlights the ways by which social power is abused, dominance is practiced, inequality is enacted and injustice prevails under the certain social and political environment.

CDA has been a fast-growing discipline which has involved new formats and materials within. In the recent decades, CDA analysts have been more inclined towards just one mode of communication, the verbal language. However, music, pictures, audio, video, coloring, font and frame sizes of news reports engage the addressee's attention. Images or pictures on print media and electronic media, and the timing of the news on TV and other forums have a sound significance, the settings of the main body of any subject matter, gestures and the uses of space organize any discourse to acquire certain purposes. (Hodge and Kress 1988: Kress and Van Leeuwen 2006).

In spite of all the diversity and development in the established field of CDA, its interdisciplinary and trans-disciplinary nature needs to be carried forward. Both CDA practitioners' and audience have a fine acquaintance with the asymmetry of the field. Because it is developing and possessing a wide range of explanation from linguistic as well as nonlinguistic mediums of communication. As according to Billig (2003), CDA is an infant discipline gradually maturing. It is so unusual that the several strengths of CDA can be understood as the causes of its weak points. The lacking of self-critical attitude on the part of CDA advocators can also be the cause of its current state of underdevelopment.

Van Dijk (1998a) believes that critical discourse analysis attempts to study and examine the text or talk to expose the discursive strategies employed to establish power, dominance, prejudice, and inequality. Also, it analyzes that how these discursive strategies or sources are used and kept in the social, political and historical contexts. Benwell (2006) comments that Van Dijk's CDA highlights the identities which emerge due to the ideological work.

\section{Statement of the Problem}

In order to view the potential of Critical Discourse Analysis, we found an untouched masterpiece in the shape of Z.A. Bhutto's speech on the war of Pakistan and India in 1965. Few of his speeches have already been critically analyzed by Khokhar (2014), Munawar (2016) etc. We found a fine space of applying CDA approaches on his speech, 
entitled as "India's Aggression". It was delivered on September 22, 1965, in UN Security Council. Also, this speech was out of the sight of many linguists, even though it had a lot of potentials to introduce the rich dimensions of CDA.

\section{Purpose of the Study}

Having predominant interest in Bhutto's speeches not only allowed to peep into the history of the native country Pakistan when it was facing a terrible war against a huge country, India, but also gave a chance to view the convincing strategies of linguistics employed by Zulfiqar Ali Bhutto to make the UNSC understand about the real problem in the region. Hence the study aimed to highlight the power of discourse with its critical analysis, featuring intersexuality, a relationship of text and the context, open and close-ended ideologies, political agendas, and cognition.

\section{E. Questions of the Study}

The particular study invokes different questions to be answered:

a. How did Zulfiqar Ali Bhutto use language as the tool to convey the real-time problem in the subcontinent?

b. Why it had been so impressive that compelled Mr. President to acknowledge and pass the required resolution of the cease-fire at borders of both Pakistan and India.

c. What were the hidden ideologies in the speech and how were they synchronized in the speech?

\section{F. Significance of the Study}

The very speech has its own significance in the history as the UNSC not only acknowledged Z.A. Bhutto's appeal but also passed the resolution which ultimately caused the cease-fire between Pakistan and India's borders. Also, this study highlights the convincing strategies used by Bhutto to instill the prevalent tension between Pakistan and India as well as the ideologies for the sake of peace in the region. Hence this speech started the peace process and provoked the researchers to evaluate and present the discourse used by Bhutto.

\section{Theoretical Framework}

There have been different approaches to critical discourse analysis by different eminent scholars like Fairclough, Wodak and Van Dijk. All of them have their own importance and significance whereas most suitable to the current study case is of Van Dijk's approach to CDA. 
Pakistan Journal of Humanities and Social Sciences, 6(4), 2018

Van Dijk's (1997) framework for critical discourse analysis introduces different discursive strategies that the dominant group of the society uses in any discourse to establish certain ideologies among the target masses.

\section{Methodology}

Firstly, we thoroughly studied and found that the speech needed an explanatory and evaluative mode of representation, which could not be made through the statistical limitations of quantitative research approach. Mayring (2000) states that, a qualitative research methodology is an approach of doing a controlled analysis of texts within their context, and this method provides a sense of following step by step models as well as content analytical rules rather than quick assessment. Therefore, the qualitative research methodology was adopted. The study needs qualitative research approach to deal with, as Straus and Corbin (1990) claim that qualitative research method allows understanding any phenomenon about which not much is known to the world.

\section{A. Data Collection}

The script of Zulfiqar Ali Bhutto's speech at the United Nation of Security Council on September 22, 1965, was taken from Bhutto's official website under the header of Z. A. Bhutto Speeches - Interviews 1948 - 1966. Also, the speech was heard through the following link https://www.youtube.com/watch?v=4HhVLBMlvHo

The speech was delivered against India's aggression towards Pakistan in the war of 1965. But it is more than a speech as it not only saved the lives of many people but also jolted us to find out the best of the language used.

\section{B. Data Analysis}

We analyzed the content qualitatively to display the different language related techniques used by Bhutto in his speech. According to Van Dijk's (1997) CDA, there have been hundreds of categories which provide a step by step textual analysis; few of them can be stated as actor, authority, categorization, comparison, disclaimers, euphemism, generalization, polarization, hyperbole, implication, vagueness, irony, presupposition, victimization and etc. According to Van Dijk (1997) texts are analyzed with three essentials: language use means the form of text or talk, communication that is pragmatics and interaction which means the social and cultural context. Hsieh and Shannon (2005) assert that an organized categorization method is employed for featuring as well as identifying themes and maps in any context of the text or talk. 
After analyzing the speech quite delicately we agreed to the point that the speech possesses a definite potential to be evaluated on the aforementioned discursive strategies.

\section{Analysis and discussion}

According to Van Dijk (2003), CDA unveils that how the mental representations of a social group are influenced by the other dominant group. He (2003) asserted that CDA is such an approach that uncovers the reasons and techniques with which power abuse, inequality, injustice, dominance, and biased attitudes of the groups are being practiced into social as well as political contexts. The genre of the speech is political which relates this case study to another dimension of discourse called political discourse analysis (PDA). Van Dijk (1998) indicates that political discourse analysis is considered as a critical approach. This contemporary critical approach of discourse especially highlights the (re)production of power, inequality of power or hegemony, and domination through certain political text or talk. Moreover, Van Dijk (1998) adds that political discourse is one of the genres of a social field called politics. Woods (2006) quotes that the discursive devices like syntax, sound and words, which frequently occur in any text or talk of the political personnel; are the essential features that help in organizing an ultimate political message.

\section{A. Textual Analysis along with Ideological Square}

According to Van Dijk (1993a, 1998), the ideological square combines a crosswise strategy presentation in which the dominant group of people poses positive self-presentation and negative other groups. Van Dijk (2000) introduced quite conceptual as well as the ideological square which formulates four principles that ultimately shape subtle ideology. These four principles are as below:

- Highlighting positive deeds of Us $\longleftrightarrow$ Highlighting negative deeds of Them

- Concealing negative deeds of Us $\longleftrightarrow$ Concealing positive deeds of Them

Hence, these two opposite poles of "Us" and "Them" distinguish the divided social figures and their essential ideologies which are (re)produced and represented at all levels of text and talk, for example in actor, authority, contrastive topics, categorization, disclaimers, euphemism, evidentiality, generalization, metaphor, hyperbole, implication, irony, polarization, presupposition, vagueness, and victimization as well as the formulations of the variable in text representation, lexicalization, syntactic forms, sound organization and images. 
Following is a small selection of discursive strategies used in order to establish an ideology as well as a solution to the real-life problem:

Actor description is one of the discursive strategies in which the ideologies decide, shape and organize the role of the actors to achieve subtle targets. The words used by Bhutto "we are fighting a war, a war imposed on us by India" provides a vivid understanding of the actors and their roles. Similarly, while describing the arbitrator he thanks "the SecretaryGeneral".

First person pronouns in the speech like "I am thankful", "I have requested", "I am not referring", "I am not saying", "We are aware", "we do not want", "we want", "we should" etc categorize positive self-representation, whereas the word "you" indicates "the Secretary General" and lastly in order to present the other group Bhutto said "India", "Indian society", "a predatory aggressor" etc. These words categorize the people based on their affiliation and role.

A fine-tuned comparison was given in terms of identification, size, number of people, intentions and etc. For example, Bhutto stated that "Pakistan is a small country", and "the might of India". Similarly, there is a contrast of intentions like Bhutto said "we do not want aggression", "we want peace..." while describing the intentions of other groups he says "India is determined to annihilate Pakistan". Further, towards the resolution of the problem, he proclaimed that "Indians may abandon their pledges and promises"; we shall never abandon ours". To highlight the comparison on the numbers of people he provides figures as "450 million people against 100 million people" These words clearly show the contrast between the positive "Us" and negative "Them".

Bhutto gallantly named the enemy and did not use euphemism throughout his speech. He used the phrases like "the issues", "a meaningful settlement between India and Pakistan", "India is determined to annihilate Pakistan", he calls India "aggressor", "a great monster" etc.

The evidence is given in any social discourse to denounce the social abuse committed by the dominant party. Bhutto provided ample shreds of evidence which ultimately made a concrete evidence of negative them and positive us. For example while describing India's aggression against Pakistan, Junagadh, against Goa, against Manavadar, and against Hyderabad, he mentioned the beginning as "ever since 1947, India has followed the road of aggression."

Generalization plays a significant role in any argumentation. Hence Z.A Bhutto generalized the aggressive attitude of India by stating the name of other powers which 
committed the same as India: "Europe, Germany committed aggression against Denmark", "Argentina or Brazil against South America", "the United States waged a war against a small country". While generalizing the idea of separation for the purpose of peace and close relationships, he gave following instances "in Europe certain countries have had to separate in order to get closer together: Sweden and Norway, for instance, had to separate".

Similarly, he further emphasized on generalizing the sense of "self-determination". Bhutto mentioned "It is not the law of God that people in Asia and Africa should be poor. And on "self-determination" he cited the names of the countries like Asia, Africa, Arab countries in Casablanca, and European countries that support "the right of self-determination of the people of Kashmir". Even, Mr. Dean Rusk, the Secretary of the United States said "the historical position is a plebiscite in Kashmir".

Hyperboles are semantic metaphoric or symbolic devices which embellish the gist of the matter. By using metaphoric words like "a predatory aggressor", "a great monster", "a great aggressor", Bhutto drew attention towards the gruesome facet of India.

Bhutto employed the technique of accusations. He accused Pakistan "is the fulcrum of India's fundamental policies". In the same way, he made another example of accusation by indicating "Them" as "Indians may abandon their pledges and promises", and to present "Us", he spoke "we shall never abandon ours".

Van Dijk's ideological square provides a sense of polarization and the cognition develops with erudite expressions among the targeted society or the recipients. To display positive and negative poles, Bhutto emphasized on the positive self representation by stating "we do not want to be exterminated", "we want our people to progress", "we do not want war, "we do not want destruction" and "we do not want disaster", "thus we want good neighborly relations with India, we want peace with India and we want friendship with India". Whereas the sentences like "our cities are being bombed indiscriminately by the might of India, by the formidable machine of the Indian armed forces", "and Pakistan, according to Indian leaders, is its enemy number one" showed the negative other representation.

Presuppositions are mostly used to presume the truth ahead caused by the prevalent factor as Bhutto stated like "we are a smaller country", which presupposed that they must have been influenced by a country which was larger in size and resources. Similarly, while presenting the condition of Asian and African leaders, Bhutto said that they, "are determined to break the barriers of the past..." which presupposed their deprived and poor condition. 
Also, words like "these are matters of record, matters of history" invoked minds to peep into the record and history to understand the subject matter.

Vagueness is a deliberate effort on the part of the speaker, as he or she deliberately purports such things which are not exactly what is stated. But Bhutto did not create any ambiguity as he gallantly portrayed the true picture of the situation by quoting the issues between Pakistan and India.

The most important task of any discourse is to portray the real victim. And Bhutto provided the true facts and figures of the situation that the two nations were facing.

\section{B. Socio-cognition (Communication) and social analysis}

Van Dijk (1998) believes that social structures and discourse structures are not associated precisely; rather they are connected through people and their minds. For Van Dijk, socio-cognition intercedes between discourse and society. Similarly, there is a strong link between society, cognition, and discourse. Van Dijk's research perspective in this context is called "socio-cognitive approach". Van Dijk (1997) emphasizes that in order to understand the discourses one must understand the contexts in which those discourse take place. In the speech, Bhutto was well aware of the positions of the oppressor, oppressed and the arbitrators, and produced quite relevant discourse which ultimately affected the audience in the form of unambiguous acknowledgment. For instances, Bhutto greeted the members of UNSC as "I am thankful to you and to the members of the Security Council...", "I am thankful to the Secretary-General". Then he named the oppressor as "Ever since 1947, India has followed the road of aggression." And while representing his country which was being oppressed, he spoke as "Pakistan is a small country...", "we do not want war", "we want peace", and etc. Bhutto did not only introduce above mentioned three entities but also developed a social cognition with the fine-tuned discourse.

Further division to Van Dijk's (1995) term socio-cognition, he defines social cognition as "the system of mental representations and processes of group members" (p.18). And in this logical term, Van Dijk (1995) adds ideologies, thus "indirectly influence the personal cognition of group members" in the way they understand the discourse along with additional actions and interactions. (p.19). In the same way, O'Halloran (2003) sums up the idea that there must be a connection between syntactic structures of text or talk and mental representations, which is ultimately controlled by the principles of discourse. According to Van Dijk's (1995) concept of mental representations, an articulation of positive terms for own group and negative terms for other group is made. Bhutto has successfully developed this 
two-dimensional cognition into the minds of the audience through his multiple dialogues using "I, we" and "they, and them". Following are Van Dijk's (1998b) beliefs for having a transparent analysis of the dichotomy of "Us" versus "Them":

a. Firstly, to analyze the context of the discourse, that includes the participants with their conflicts. Whether these differences belong to their social setting, historical and political backgrounds.

b. Secondly, the analysis of the groups on the basis of power relations and the differences among the groups.

c. Thirdly, to identify positive and negative opinions about "Us" versus "Them" respectively.

d. Fourthly, to create an explicit presupposition as well as its implications.

e. Fifthly, to investigate and highlight all the lexical choices and syntactic structures, which facilitate (de)emphasize opinions on the polarized group.

According to the above paradigm, we thoroughly examined the context of Bhutto's speech and found the traces of historical, political and social backgrounds of conflicts. For instance, words like "during the eighteen years of our independence", "ever since 1947, "from 1947 we have been faced with this situation", show historical conflict. Similarly, on political and social grounds Bhutto emphasized on the separation of Pakistan as "we know that in Europe certain countries have had to separate in order to get closer together", he quotes the example of "Sweden and Norway". Further to reinforce the idea of the creation of Pakistan Bhutto said "the basic idea in the creation of Pakistan was that the areas occupied by the Muslim majority should form Pakistan. This basic principle was accepted by the Indian leaders." And while articulating the true purpose of the creation of Pakistan, Bhutto commented that Pakistan was made, "to establish a permanent peace, a permanent understanding between the people of India and the people of Pakistan."

In order to highlight the social ethics Bhutto accentuated on the good neighborly relations as he commented, "a peace for all time, a peace in which India and Pakistan can live as good neighbors", we are neighbors and want to live as good neighbors". Similarly to support the idea, he further claimed that all the efforts for peace would be in vain "if we are not able to establish good neighborly relations with India", and acknowledged that India was "our principle neighbor" in terms of historical, geological, and political grounds.

The political differences were represented as "Jammu and Kashmir dispute", “... a meaningful and lasting solution to the problem of Jammu and Kashmir", "Sino-Indian 
Pakistan Journal of Humanities and Social Sciences, 6(4), 2018

conflict" etc. Bhutto's dialogues showed how a dominant group exercised its power, "a naked, predatory unwarranted aggression by 450 million people against 100 million people" then he gave a comparison as "a war of chauvinism and aggrandizement by a mighty neighbor against a small country."

The identification of the positive and negative opinions can be viewed through the dialogues "we do not want", "...we are not interested in war", "we do not want aggression, "we do not want conflict," "we want peace in order that our people can develop" and etc. To show the negative side of "them" Bhutto alleged that a war, "which has been imposed on us by a predatory aggressor", "we are facing a great monster, a great aggressor...", "Today we are fighting a war, a war imposed on us by India..." and according to Indian leaders Pakistan "is its enemy number one" and etc.

All the aforesaid dialogues by Bhutto possessed a formal structure; the lexical choices and syntactic structures employed, are clearly emphasizing "Us" and deemphasizing "Them". Through such a deep analysis we believe that the implication of Van Dijk's critical approaches of discourse, socio-cognition, and social analysis provide the unequivocal representation of the real-time problem. The application of Van Dijk's critical discourse analysis has not only helped us to describe the phenomenon but also has provided the sense of contemplations and presuppositions about the two neighbor countries, Pakistan and India.

\section{Conclusion}

The most important purpose of the present study was to discover the linguistic features employed to display the Bhutto's ideology as well as the socio-cognition developed through his selection of words. As far as the CDA is concerned, the speech is quite rich in a range of words. The selection of terminologies like "modus vivendi", "kudos" and "Wilsonian right" and "Wilsonian concept" is also very impressive and relevant. These words are self-explanatory as there are ideologies behind these words. The diction that Bhutto employed in his speech was clear, formal, direct, bold, and erudite. It not only impressed the Security Council but also the people of all times. The grammatical features of the speech form the accurate sentences to provide the true bifurcation of Van Dijk's ideological square of "Us" vs. "Them". In the speech "us" is produced as the victim in the formal part of the speech whereas in the latter part of the speech "us" is shown as the attacker as well but on condition of "self-respect". Similarly, "them" remains antagonist to "us" in the formal part of the speech whereas in the latter Bhutto gives another dimension to the heated situation by using the words like "neighbor", and "a principle neighbor" which mould "them" into another 
meaning. Unlike the conventional politicians, Bhutto proclaimed the truth, the fact and the real problem of the sub-continent which resulted in the expected settlement. Also, the social analysis of the speech suggests that Bhutto had put his efforts so well to show the victim and the tyrant so that the real settlement could be made for once and all.

The study has been delimited owing to lack of time and resources. The first limitation is of the selection of leader. Although there have been several leaders in the history of the world generally and Pakistan particularly who delivered famous addresses, yet Bhutto has been chosen for the current study. It has been done so because Bhutto's speeches have been considered rich for linguistic data. Another limitation of the study is the choice of one speech and not all the speeches he delivered throughout his political career. It is because other speeches of Bhutto have already been analyzed by Khokhar (2014), Munawar (2016) etc. The final limitation relates to the application of model for analysis. Although there are several models for doing critical discourse analysis of a speech yet Van Dijk's model has been considered appropriate and used in the current study.

The benefits of the present study can be discussed at two levels i.e. theoretical and practical. At a theoretical level, the critical discourse analysis has brought us to the position of understanding that language can be used to construct, (re)produce, and maintain the ideology that influences minds to achieve set goals. And on the practical contribution, this study stirs the contemporary linguists or experts in finding and analyzing the speeches of the great leaders.

\section{A. Recommendations}

Bhutto has delivered many speeches since 1948 to 1965 (which may be approached from his official website). Bhutto - being the representative of Pakistan, delivered these speeches on the different national and international forums. Therefore, his speeches are of formal capacity and possess a profound potential to be critically analyzed. Previous as well as the current study draw the attention of critical discourse analysts to view political speeches of Pakistani leaders in general and Bhutto's speeches in particular. 
Pakistan Journal of Humanities and Social Sciences, 6(4), 2018

\section{References}

A decision against the resolution 211 by The UNSC: Lbid., document S/6683, Retrieved on January 22, 2018 from: https://undocs.org/S/RES/211(1965)

Anthonissen, C. (2001) 'On the Effectivity of Media Censorship: An Analysis of Linguistic, Paralinguistic and other Communicative Devices Used to Defy Media Restrictions'. $\mathrm{PhD}$ thesis, University of Vienna, Vienna.

Benwell, B. \& Stokoe, E. (2006). Discourse and identity, Edinburgh: Edinburgh University Press.

Billig, Michael. 2003. "Critical Discourse Analysis and the Rhetoric of Critique." Gilbert Weiss and

Ruth Wodak, eds. Critical Discourse Analysis. Houndmills: Palgrave Macmillan.35- 46.

Bhutto Z. A. (1965). Speeches 1948 - 1965. Retrieved on January 22, 2018 from https://www.bhutto.org/1957-65.php

Critical discourse analysis (PDF Download Available). Retrieved on January 22, 2018, from: https://www.researchgate.net/publication/228921006_Critical_discourse_analysis

Fairclough, N. (1992). Discourse and Social Change (Vol. 73). Cambridge: Polity press.

Fairclough, N. (1995) Critical Discourse Analysis. London: Longman.

Gee, James P. (1999). An Introduction to Discourse Analysis. London: Routledge.

Hsieh, H. F., \& Shannon, S.E. (2005). Three approaches to qualitative content analysis. Qualitative Health Research, 15(9), 1277-1288.

Hodge, Robert and Gunther Kress. 1988. Social Semiotics. London: Polity Press.

Junejo C. A. (1996). Zulifkar Ali Bhutto A Memoir by Chakar Ali Junejo. Retreived January 19, 2018,from https://www.bhutto.org/images/books_Pictures/ZULFIKAR\%20ALI\%20BHUTTO_ ME MOIR_CHAKIR_JUNEJO.pdf

Kress, Gunther and van Teun Leeuwen. 2006. Reading Images. The Grammar of Visual Design. London: Routledge.

Levinson, S. C. (2000). Presumptive Meanings: The Theory of Generalized Conversational Implicature. Cambridge, MA: MIT Press.

Mayring, P. (2000). Qualitative content analysis. Forum: Qualitative Social Research, 1(2). Retrieved July 28, 2008, from http://217.160.35.246/fqs-texte/2-00/2- 00mayringe.pdf

O"Halloran, Kieran. 2003. Critical Discourse Analysis and Language Cognition. Edinburgh: Edinburgh UP.

Strauss,A.,\&Corbin,J.(1990a).Basics of qualitatitative research: Techniques and procedures for developing grounded theory. Newbury Park, CA: Sage

Van Dijk, T.A. (1993) 'Principles of critical discourse analysis', Discourse \& Society, 4, pp. $249-83$

Van Dijk, A.T. (1997). Discourse as structure and process of discourse studies: A multidisciplinary

introduction. Volume I. SAGE Publications, London.

Van Dijk, T. A. (1997). Discourse as interaction in society. In T. A. van Dijk (Ed.), Discourse as social interaction (pp. 1-37). London: Sage.

Van Dijk, T.A. (1998b). Opinions and Ideologies in the Press. In Bell, Allan and Peter Garrett (Eds.). Approaches to Media Discourse. Oxford: Blackwell

Van Dijk, T. A. (2003). 18 Critical discourse analysis. In D. Tannen, D. Schiffrin \& H. Hamilton (Eds.), Handbook of discourse analysis. (pp. 352-371). Oxford: Blackwell. 
Van Dijk, T. A. (1993a). Elite discourse and racism. Newbury Park, CA: Sage Publications, Inc.

Van Dijk, T. A. (1998). Towards a theory of context and experience models in discourse processing. In H. Van Oostendorp \& S. Goldman (Eds), The construction of mental models during reading. Hillsdale, $\mathrm{NJ}$ : Erlbaum.

Van Dijk, T.A. (1998a). Critical discourse analysis. Retrieved on January 22, 2018 from: http://www.hum.uva.nl/teun/cda.htm

Van Dijk, T. A. (2009). Critical discourse studies: A socio-cognitive approach. Methods of critical discourse analysis. 2(1), 62-86.

Van Dijk, T.A. (1988a) News Analysis :Case Studies of International and National News in the Press. New Jersey: Lawrence Erlbaum Associates.

Woods, N. (2006). Describing Discourse: A Practical Guide to Discourse Analysis. United Kingdom: Hodder Headline Group. 